\title{
Plant growth, yield and fruit quality of Clementine mandarin selections under subtropical climate in Brazil
}

\author{
Simone Rodrigues da Silva ${ }^{1}$, Eduardo Augusto Girardi², Magno Guimarães Santos ${ }^{2}$, \\ Tatiana Eugenia Cantuarias-Avilés ${ }^{1}$, Eduardo Sanches Stuchi ${ }^{2}$ \\ Abstract - In Brazil, few mandarin (Citrus reticulata, Blanco) cultivars are being currently exploited, \\ limiting the availability of fresh fruit in the local market. This study was aimed to investigate the \\ performance of 15 Clementine mandarin selections and 3 hybrids, seeking for alternative varieties for \\ production under subtropical conditions. Fifteen Clementine selections, namely: 'Oroval-SRA335', \\ 'Tomatera-SRA535', 'Reina-SRA534', 'Bruno-SRA531', 'Nules-SRA389', 'Ragheb-SRA386', \\ 'Oroval-Y45', '2-Kr-Monreal', 'Commune-SRA88', 'Commune-SRA85', 'Caffin-SRA385', 'De \\ Nules-VCR', 'Commune-SRA92', 'Clemenules-EECB128' and 'Marisol-EECB126'; three hybrids \\ ('Clemelin-IVIA335', 'Caçula-1' and 'Caçula-3') and the standard commercial varieties 'Ponkan' and \\ 'Cravo', grafted on 'Swingle' citrumelo [C. paradisi Mafad. cv. 'Duncan' x Poncirus trifoliata (L.) Raf.], \\ were evaluated in Bebedouro, São Paulo State, Brazil, from 2004 to 2008. The experimental plot was \\ planted in 2001 with the 20 genotypes disposed in a randomized block design, with three replications \\ and two plants per plot. The 'Cravo' variety and the 'Clemelin-IVIA335' hybrid presented the smallest \\ plant size. The selections 'Cravo', 'Caffin-SRA385', 'Clemelin-IVIA335', 'Marisol-EECB126' and \\ 'Ragheb-SRA386' had the smallest cumulative yield. Fruits of 'Caçula-1' had the highest soluble solids \\ content and those of 'Caçula-3' showed the highest juice content. Among the Clementine selections, \\ 'Bruno-SRA531', 'Clemenules-EECB128', 'De Nules-VCR' and 'Reina-SRA534' reached earlier \\ maturity. In terms of yield efficiency, 'Ponkan' trees performed similarly or outperformed the other \\ selections, with larger fruits and earlier ripening. The 'Reina-SRA534' selection outstood due to its \\ high fruit yield and quality, with medium fruit size and early bearing, while 'De Nules VCR' and \\ 'Tomatera-SRA 535' had high yield, low alternate-bearing and fine fruit quality, despite of their large \\ plant size. Good performance of Clementine selections and hybrids encourages further studies on \\ cultural practices for growing this group of mandarins under subtropical climatic conditions. \\ Index Terms: citrus, ripening season, fresh fruit.

\section{Desenvolvimento, produção e qualidade de frutos de seleções de tangerineira Clementina sob clima subtropical no Brasil}

\begin{abstract}
Corresponding author: srsilva@usp.br

Received: April 03, 2017.

Accepted: October 04, 2017.
\end{abstract}

Copyright: All the contents of this journal, except where otherwise noted, is licensed under a Creative Commons Attribution License.

\section{(cc) $\mathrm{EY}$}

Resumo - No Brasil, poucas cultivares de tangerineira (Citrus reticulata, Blanco) são exploradas atualmente, o que limita a oferta de frutas frescas no mercado. Este estudo avaliou o desempenho de 15 seleções e 3 híbridos de tangerineira Clementina, visando a buscar alternativas para produção em condições subtropicais. Quinze selecções de Clementina ('Oroval-SRA335', 'Tomatera-SRA535', 'Reina-SRA534', 'BrunoSRA531', 'Nules-SRA389', 'Ragheb-SRA386', 'Oroval-Y45', '2-Kr-Monreal', 'Commune-SRA88', 'Commune-SRA85', 'Caffin-SRA385', 'De Nules-VCR', 'Commune-SRA92', 'Clemenules-EECB128' e 'Marisol-EECB126'); três híbridos ('Clemelin-IVIA335', 'Caçula-1' e 'Caçula-3') e duas cultivares comerciais controle ('Ponkan' e 'Cravo'), enxertadas em citrumelo 'Swingle' [C. paradisi Mafad. cv. 'Duncan' x Poncirus trifoliata (L.) Raf.], foram avaliadas no município de Bebedouro-SP, Brasil, de 2001 a 2008. O pomar experimental foi plantado em 2001, com os 20 genótipos dispostos em blocos ao acaso, com três repetições de duas plantas por parcela. O controle 'Cravo' e o híbrido 'Clemelin-IVIA335' apresentaram o menor vigor das plantas. As seleções 'Cravo', 'Caffin-SRA385', 'Clemelin-IVIA335', 'Marisol-EECB126' e 'Ragheb-SRA386' tiveram as menores produções acumuladas. Os frutos do híbrido 'Caçula-1' apresentaram o maior conteúdo de sólidos solúveis, e os do 'Caçula-3', o maior teor de suco. As seleções 'Bruno-SRA531', 'Clemenules-EECB 128', 'De Nules-VCR' e 'Reina-SRA534' atingiram o início de produção antes das demais seleções de Clementina. Em termos de eficiência produtiva, a variedade 'Ponkan' igualou-se ou até ultrapassou as seleções, com frutos maiores e de maturação precoce. A seleção 'Reina-SRA534' destacou-se pelos frutos de tamanho médio e precocidade de produção, enquanto 'De Nules VCR' e 'Tomatera-SRA535' apresentaram rendimento elevado, apesar do maior tamanho de planta. O bom desempenho das seleções e dos híbridos de Clementina deste estudo estimula a avaliação de práticas culturais para o cultivo desse grupo em clima subtropical.

Termos para indexação: cítrus, época de maturação, fruta fresca.

${ }^{1}$ Universidade de São Paulo. Piracicaba-SP, Brazil. E-mails: srsilva@usp.br; tatiana.cantuarias@gmail.com 2Embrapa Mandioca e Fruticultura, Cruz das Almas-BA, Brazil. E-mails: eduardo.girardi@embrapa.br; magno.santos@embrapa.br; eduardo. stuchi@embrapa.br 


\section{Introduction}

The global production of mandarins in 2016 reached 32.8 million $t$ (FAO, 2018). Brazil occupied the sixth position in the world production rank, with nearly $1,000,000 \mathrm{t}$, harvested from approximately 50,000 ha, being the State of São Paulo the main producer, accounting for $35 \%$ of the national production (IBGE, 2018).

The local market of mandarins is limited to a few varieties. Mandarin 'Ponkan' (Citrus reticulata Blanco) is the most planted and is the most preferred variety by Brazilian consumers, because of its pleasant taste and ease of peeling, with low acidity and high sugar content. 'Murcott' tangor [C. reticulata Blanco x C. sinensis (L.) Osbeck] is the second most planted variety, followed in smaller proportions by 'Cravo' (C. reticulata) and 'Montenegrina' mandarins (C. deliciosa Tenore) (PIO et al., 2005).

'Ponkan' mandarin is harvested from May to July, while tangor 'Murcott' is harvested from August to November (CEAGESP, 2014a). However, the 'Murcott' mandarin has numerous seeds and is more difficult to peel (PIO et al., 2005), being also highly susceptible to brown spot caused by Alternaria alternata (SOLEL et al., 1997; PERES et al., 2003).

'Clementines' ( $C$. clementina Hort. ex Tanaka) have been poorly exploited in Brazil. They present low susceptibility to Alternaria brown spot, variable fruit size and variable skin color, depending on the variety, with a firm and adherent skin, that peels off easily, and fruits with a few or no seeds at all when grown in isolated plots (HODGSON, 1967). In Brazil few studies have been published regarding the production and fruit quality of Clementine selections (PIO et al., 2006; SILVA et al., 2009).

The 'Swingle' citrumelo rootstock [C. paradisi Mafad. cv. 'Duncan' x Poncirus trifoliata (L.) Raf.] is tolerant to citrus sudden death (CSD) (BOVÉ and AYRES, 2007), citrus tristeza virus (CTV) and gummosis caused by Phytophthora spp. However, this rootstock is less tolerant to drought and shows incompatibility with some mandarin hybrids such as 'Murcott' tangor (MOLINARI et al., 2004). In Egypt and Cyprus, clementines have good fruit yield and quality when grafted on 'Swingle' citrumelo (GEORGIOU, 2002; BASSAL, 2009).

Therefore, the horticultural performance of fifteen Clementine mandarin selections, three hybrids and the 'Ponkan' and 'Cravo' varieties grafted onto Swingle citrumelo, was evaluated under the subtropical climatic conditions of São Paulo State, in Brazil, with the aim of selecting alternative mandarin cultivars for increasing fruit supply into the local market.

\section{Materials and Methods}

The experiment was conducted in the county of Bebedouro, in the northern region of São Paulo State,

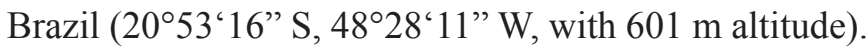
Climate is Köeppen's Cwa, i.e., subtropical highland climate (Figure 1). The experimental plot was planted in February 2001 in a $6.0 \mathrm{~m} \times 3.0 \mathrm{~m}$ spacing ( 555 trees per ha), on a haplustox soil - a deep dark red oxisol, eutrophic, endoalic, with a moderate A horizon with clayey texture (38\% clay) $\left[\mathrm{pH}(\mathrm{CaCl} 2)=5.7 ; \mathrm{CEC}=55 \mathrm{mmol}_{\mathrm{c}} \mathrm{dm}^{-3}\right.$ in the $0-20 \mathrm{~cm}$ of upper surface soil layer]. The plot was drip irrigated since 2006, after five years from planting. Field evaluations were concluded in 2008, at the seventh year after planting.

Dolomitic limestone was applied before installing the experiment, ( $70 \%$ acid neutralizing capacity in order to increase soil base saturation to $70 \%$ ) and it was reapplied when the soil base saturation reached $60 \%$. The mean annual fertilization rates applied per tree from 2001 to 2008 were $213 \mathrm{~g}$ of Nitrogen, $121 \mathrm{~g}$ of P2O5 and 119 $\mathrm{g}$ of $\mathrm{K} 2 \mathrm{O}$. The plants were grown under the standard recommended practices for mandarin cultivation in Brazil, with no fruit thinning and pruning. Weeds were controlled by mechanical cutting of the inter-row natural vegetation (Brachiaria spp.), supplemented by herbicide applications along the tree rows.

Fifteen Clementine mandarin selections were evaluated, namely: 'Oroval-SRA335', 'TomateraSRA535', 'Reina-SRA534', 'Bruno-SRA531', 'NulesSRA389', 'Ragheb-SRA386', 'Oroval-Y45', '2-KrMonreal', 'Commune-SRA88', 'Commune-SRA85', 'Caffin-SRA385', 'De Nules-VCR', 'Commune-SRA92', 'Clemenules-EECB 128' and 'Marisol-EECB 126'; three hybrids: 'Clemelin-IVIA335' [C. clementina $\times$ C. sinensis (L.) Osbeck cv. Hamlin], 'Caçula-1' and 'Caçula-3' (C. clementina $\times$ C. reticulata cv. 'Cravo'); and the commercial varieties 'Ponkan' and 'Cravo' $(C$. reticulata), as standard varieties. All the scion selections were virus and viroid-free. Budwood was collected at the Citrus Experimental Station of Bebedouro (EECB), in the northern São Paulo State, Brazil, from a collection maintained under a screen house, where the selections were grafted onto nucellar seedlings of 'Swingle' citrumelo [C. paradisi Mafad. cv. 'Duncan' x Poncirus trifoliata (L.) Raf.].

The genotypes evaluated in this study were originally introduced from the SRAAgrumes Agricultural Research Station, in Corsica, France, except for 'Ponkan' and 'Cravo', which were obtained from the APTA Citrus "Sylvio Moreira" Gen Bank of the Agronomic Institute (IAC), in Cordeirópolis, São Paulo State, Brazil. 'Caçula-1' and 'Caçula-3' are local hybrids obtained from a crossing involving 'Clementine' and 'Cravo' as parentals, performed by Prof. Dr. Luiz Carlos Donadio 
in 1972 at the Universidade Estadual Paulista "Júlio de Mesquita Filho" (Unesp/FCAV), in Jaboticabal,São Paulo State, Brazil. These Clementine selections did not present Alternaria brown spot symptoms on leaves and fruits in previous studies at the EECB (REIS et al., 2007; SOUZA et al., 2009), one of the reasons why they were selected for further horticultural evaluation in this study.

The following variables were measured: plant height $(\mathrm{PH})$, assessed from the ground to the top of the tree; mean canopy diameter (CD), calculated by averaging tree width measured in parallel $\left(\mathrm{D}_{1}\right)$ and perpendicular $\left(\mathrm{D}_{\mathrm{r}}\right)$ directions to the tree row; canopy volume $(\mathrm{CV})$, calculated by the expression $\mathrm{CV}=(\pi / 6) \times \mathrm{PH} \times \mathrm{D}_{1} \times \mathrm{D}_{\mathrm{r}}$ (CANTUARIAS-AVILÉS et al., 2010), and the mean annual growth rate (AGR), calculated from the mean annual variation of CV from 2006 to 2008 . Tree size was annually measured from 2006 to 2008 . Cumulative yield - CY - was measured in the 2004-2008 period (years 4 to 7 from planting). The percentage of cumulative yield up to the second commercial harvest (PCY2) was used to estimate early-bearing (CANTUARIAS-AVILÉS et al., 2010). Mean yield efficiency (YE) for the 2006-2008 period was calculated from the ratio between annual yield $\left(\mathrm{kg} \mathrm{plant}^{-1}\right)$ and canopy volume $\left(\mathrm{m}^{3}\right.$ plant $\left.^{-1}\right)$. Alternate bearing index (ABI) for the period 2004-2008 was calculated as follows: $A B I=[1 /(n-1)] \times\left\{\left[\left|a_{2}-a_{1}\right| /\left(a_{2}+\right.\right.\right.$ $\left.\left.\left.a_{1}\right)\right]+\left[\mid a_{3}-a_{2} / /\left(a_{3}+a_{2}\right)\right]+\ldots+\left[\mid a_{n}-a_{n-1} / /\left(a_{n}+a_{n-1}\right)\right]\right\}$, where $\mathrm{n}=$ total number of years evaluated, and $\mathrm{a}_{1}, \mathrm{a}_{2}, \ldots, \mathrm{a}_{\mathrm{n}-1}$, $\mathrm{a}_{\mathrm{n}}=$ production in the corresponding year (STENZEL et al., 2003).

Fruit quality was assessed in samples of 10 fruits per plot that were annually collected in May, according to the visual maturation and softness. In these samples, the following variables were determined: fruit weight, diameter and height; total soluble solids content (TSS), measured with a refractometer (Palette PR-101, ATAGO, Tokyo, Japan); total acidity (TA), obtained by titration with sodium hydroxide $(0.3125 \mathrm{~N})$; ratio, calculated as TSS/ TA and juice yield (\%), determined in an extractor (Otto 1800, OIC, Limeira, São Paulo, Brazil).

The trial was set following a randomized block design with 20 treatments (genotypes), three replications and three trees in each plot. Results were submitted to the analysis of variance and means were grouped by the ScottKnott test $(\mathrm{P} \leq 0.05)$. Data that did not meet normality and variance homogeneity assumptions were submitted to an arcsine square root transformation. Statistical analyses were performed using the program AgroEstat (BARBOSA and MALDONADO JR., 2015).

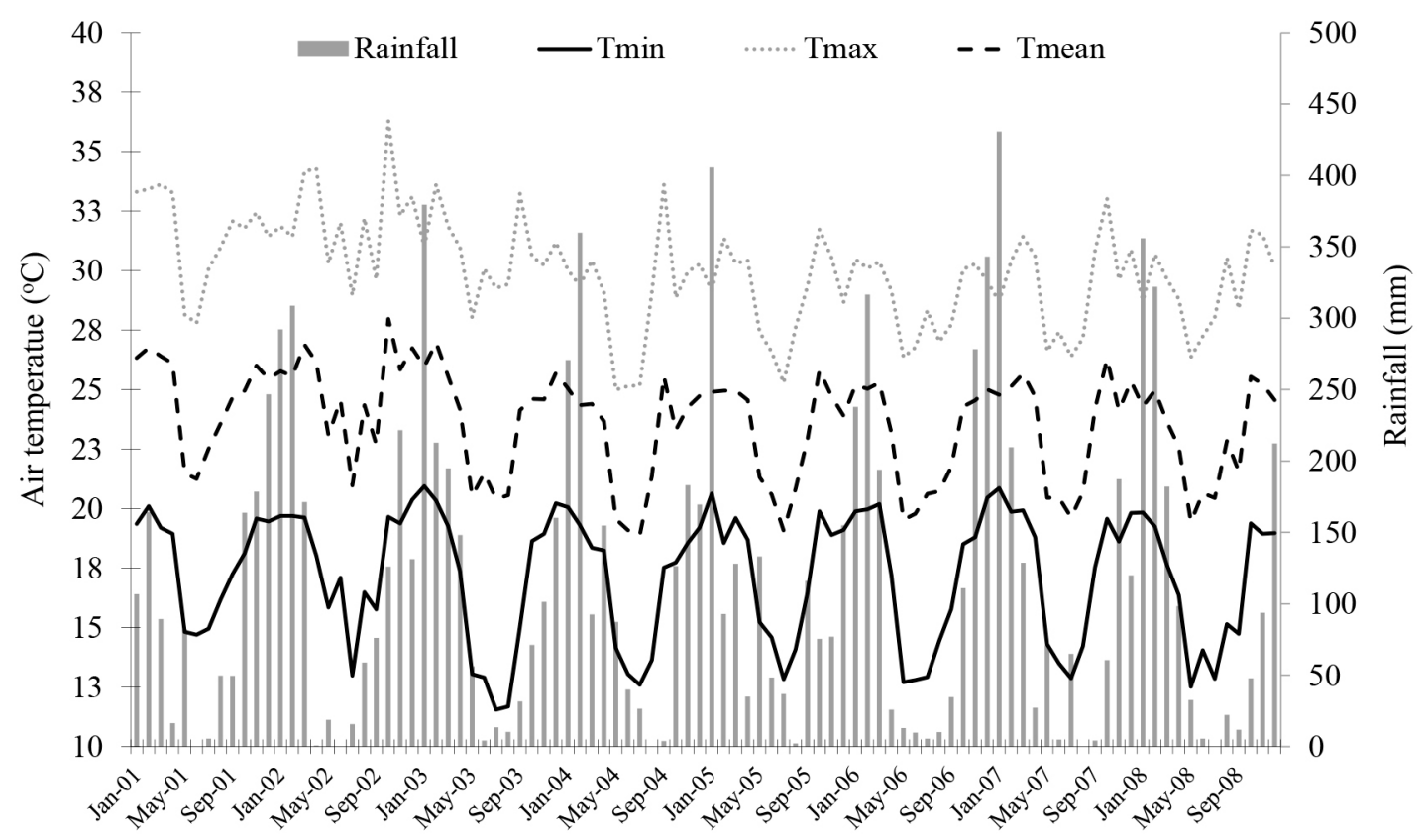

Month-year

Figure 1. Monthly rainfall and air temperatures (maximum, minimum and mean) in the experimental site. Bebedouro, São Paulo, Brazil. 2001 - 2008. 


\section{Results and discussion}

In the 2006-2008 period, the largest canopy volume $(\mathrm{CV})$ were observed in the following selections: 'Tomatera-SRA535', 'De Nules VCR', 'Oroval-SRA335', 'Oroval-Y45', 'Nules-SRA38', '2 Kr Monreal' and 'Caffin-SRA385', while the 'Clemelin-IVIA335' mandarin had smaller CV than 'Ponkan' mandarin. Largest plant heights were also recorded in the selections showing higher $\mathrm{CV}$, as well as in the three Commune selections.

In terms of $\mathrm{CD}$, four groups of selections were identified (Table 1): (a) high CD (3.48 to $4.05 \mathrm{~m}$ ): 'OrovalSRA335', 'Tomatera-SRA535', 'Nules-SRA389', 'Oroval-Y45', '2-Kr-Monreal', 'Caffin-SRA385' and 'De Nules VCR'; (b) selections with CD between 3.00 and $3.32 \mathrm{~m}$, all more vigorous than the 'Cravo' and 'Ponkan' standard selections: 'Reina-SRA534', 'Ragheb-SRA386', 'Commune-SRA88', 'Commune-SRA85', 'CommuneSRA92', 'Clemenules-EECB128', 'Marisol-EECB126' and the hybrids, 'Caçula-1' and 'Caçula-3', (c) the 'BrunoSRA531' selection, with CD similar to that of 'Ponkan' mandarin, and (d) the 'Clemelin-IVIA335' hybrid and the 'Cravo' standard variety, both with smallest CV values (Table 1).

Smallest plant heights - PH - were recorded in the'Clemelin-IVIA335', 'Bruno-SRA531', 'ClemenulesEECB128', 'Marisol-EECB126' 'and 'Caçula-3' selections, all with $\mathrm{PH}$ similar to the 'Cravo' standard variety, with $\mathrm{PH}<3.07 \mathrm{~m}$. All the other selections showed higher PH values, varying between 3.18 and $3.72 \mathrm{~m}$, similar to that of the 'Ponkan' standard variety (Table 1).

For canopy volume - CV - the genotypes were classified into four different groups, namely: (a) the 'Tomatera-SRA535' and 'De Nules VCR' selections, with largest CV values (27.6 and $30.4 \mathrm{~m}^{3}$, respectively); (b) the 'Oroval-SRA 335', 'Nules-SRA389', 'Oroval-Y45', '2-Kr-Monreal', 'Caffin-SRA385', 'Commune-SRA92' and 'Caçula-1' genotypes, with intermediate $\mathrm{CV}$ values (19.8 to $23.0 \mathrm{~m}^{3}$ ), and (c) the 'Clemelin-IVIA355' hybrid and the 'Cravo' standard variety, both showing the lowest mean CV (Table 1).

Largest annual canopy growth (ACG) rates in the 2006-2008 period were recorded in plants of 'TomateraSRA535', 'Nules-SRA389', 'Caffin-SRA385', 'De Nules VCR' and 'Oroval-SRA 335' selections (ACG $>7.5 \mathrm{~m}^{3}$ ). The 'Ragheb-SRA 386' and the 'Oroval-Y45' selections, the two 'Caçula' hybrids and the three Commune selections had intermediate ACG rates, $\left(4.88 \mathrm{~m}^{3}\right.$ to $\left.6.61 \mathrm{~m}^{3}\right)$, similar to that of the 'Ponkan' standard variety. Lowest ACG rates $\left(<4.0 \mathrm{~m}^{3}\right)$ were observed in 'Clemelin-IVIA335', 'BrunoSRA531' and in the 'Cravo' standard variety (Table 1).

In this study, 'Ponkan' trees were 3.57 meterhigh, smaller than the average tree height of 4.50 meters recorded for this variety by Pio et al. (2006) in Capão Bonito, southern São Paulo State, under cooler and wetter weather conditions. In another study conducted in the Guilan province, in Iran, 'Ponkan' mandarin trees were also taller, but had smaller diameter than the 'Cadoux' clementine (ABEDI-GHESHLAGHI and FIFAEI, 2012). Scion/rootstock combinations resulting in small and highly productive plants are more suitable for establishing highdensity plantings that allow easy-to-pick orchards. For this purpose, mandarin genotypes with smaller tree size would be definitely more appropriate and should be preferred.

When analyzing the cumulative yield - CY - in the 2004-2008 period (Table 2), the genotypes were classified into three different groups : a) highest yielding selections $\left(98.6<\mathrm{CY}<156.6 \mathrm{~kg}\right.$ plant $^{-1}$, equivalent to 54.8 to 87.0 $\left.t^{t} a^{-1}\right)$, including the 'Ponkan' and all the other evaluated genotypes, except for the 'Caffin-SRA385' mandarin; b) selections with intermediate $\mathrm{CY}(65.6<\mathrm{CY}<89.0$ $\mathrm{kg}$ plant $^{-1}$, equivalent to 36.4 to $49.4 \mathrm{t} \mathrm{ha}^{-1}$ ), including the 'Clemelin-IVIA335' hybrid, the 'Rhageb SRA386' and 'Marisol-EECB126' selections and the 'Cravo' standard variety, and c) the 'Caffin-SRA385' selection, that showed a very low CY during the evaluated period, with only $16.5 \mathrm{~kg}$ plant $^{-1}\left(9.1 \mathrm{t} \mathrm{ha}^{-1}\right)$, and its first harvest recorded only in 2006 (five years after planting). Under Mediterranean climatic conditions in Corsica, France, the 'Carrizo' citrange, used as rootstock for the 'CommuneSRA92' mandarin, induced the highest mean yield (62.00 $\mathrm{kg}$ plant $^{-1}$ ) along a 9-year time period (HUSSAIN et al., 2013), being this value smaller than the yields observed in this study for all selections in the first five harvest seasons.

Plants of the 'Nules SRA389', 'Ragheb-SRA386', 'Oroval-Y45' and 'Caffin-SRA385' selections together with the 'Caçula-1' and 'Caçula-3' hybrids and the 'Cravo' and 'Ponkan' standard varieties had very high $\mathrm{ABI}$ values (between 0.53 and 0.72 ), while the other selections showed lower ABI values (from 0.28 to 0.46 ) (Table 2). High ABI observed in this study may be partially explained by the fact that no fruit thinning was performed. In the other hand, low ABI values, as those observed on most of the Clementine selections evaluated in this study, were also reported by Abedi-Gheshlaghi and Fifaei (2012) and by Pio et al. (2006). In the State of Paraná, in the southern region of Brazil, 'Ponkan' trees cultivated without irrigation onto seven rootstocks, different from 'Swingle' citrumelo, also reached low ABI values (between 0.28 and 0.48), depending on the rootstock (STENZEL et al., 2003).

Most of the Clementine selections had significant earlier bearing - PCY2 - than the Ponkan standard variety (Table 2), with the selections 'Reina-SRA534', 'BrunoSRA531', 'De Nules VCR' and 'Clemenules EECB 128' being the most precocious ones, even when compared with 'Cravo' mandarin. Nonetheless, two Clementine selections, the 'Ragheb-SRA 386' and the 'Caffin-SRA', showed very poor PCY2 in the 2004-2008 period. 
Table 1. Mean canopy diameter (CD), plant height (PH) and canopy volume (CV) in 2008 and mean annual growth rate (AGR) in the 2006-2008 period for twenty mandarin genotypes grafted on 'Swingle' citrumelo. Bebedouro, São Paulo State, Brazil.

\begin{tabular}{lcccc}
\hline Genotypes & $\begin{array}{c}\mathrm{CD} \\
(\mathrm{m})\end{array}$ & $\begin{array}{c}\text { PH } \\
(\mathrm{m})\end{array}$ & $\begin{array}{c}\mathrm{CV} \\
\left(\mathrm{m}^{3}\right)\end{array}$ & $\begin{array}{c}\text { AGR } \\
\left(\mathrm{m}^{3} \text { year }\right.\end{array}$ \\
\hline '2 Kr Monreal' & $3.53 \mathrm{a}$ & $3.34 \mathrm{a}$ & $22.2 \mathrm{~b}$ & $6.09 \mathrm{~b}$ \\
'Bruno-SRA531' & $2.83 \mathrm{c}$ & $2.95 \mathrm{~b}$ & $12.8 \mathrm{c}$ & $3.88 \mathrm{c}$ \\
'Caçula-1' & $3.27 \mathrm{~b}$ & $3.72 \mathrm{a}$ & $21.4 \mathrm{~b}$ & $6.24 \mathrm{~b}$ \\
'Caçula-3' & $3.18 \mathrm{~b}$ & $2.91 \mathrm{~b}$ & $15.3 \mathrm{c}$ & $5.07 \mathrm{~b}$ \\
'Caffin-SRA385' & $3.51 \mathrm{a}$ & $3.24 \mathrm{a}$ & $21.0 \mathrm{~b}$ & $7.62 \mathrm{a}$ \\
'Clemelin-IVIA335' & $2.27 \mathrm{~d}$ & $2.73 \mathrm{~b}$ & $7.5 \mathrm{~d}$ & $2.27 \mathrm{c}$ \\
'Clemenules-EECB128' & $3.28 \mathrm{~b}$ & $3.07 \mathrm{~b}$ & $17.3 \mathrm{c}$ & $6.26 \mathrm{~b}$ \\
'Commune-SRA85' & $3.01 \mathrm{~b}$ & $3.18 \mathrm{a}$ & $16.1 \mathrm{c}$ & $5.02 \mathrm{~b}$ \\
'Commune-SRA88' & $3.11 \mathrm{~b}$ & $3.22 \mathrm{a}$ & $17.4 \mathrm{c}$ & $5.36 \mathrm{~b}$ \\
'Commune-SRA92' & $3.32 \mathrm{~b}$ & $3.37 \mathrm{a}$ & $19.8 \mathrm{~b}$ & $5.84 \mathrm{~b}$ \\
'Cravo' & $2.08 \mathrm{~d}$ & $2.96 \mathrm{~b}$ & $7.3 \mathrm{~d}$ & $1.93 \mathrm{c}$ \\
'De Nules VCR' & $3.87 \mathrm{a}$ & $3.52 \mathrm{a}$ & $27.6 \mathrm{a}$ & $9.52 \mathrm{a}$ \\
'Marisol-EECB126' & $3.19 \mathrm{~b}$ & $2.98 \mathrm{~b}$ & $17.6 \mathrm{c}$ & $5.83 \mathrm{~b}$ \\
'Nules-SRA389 & $3.53 \mathrm{a}$ & $3.43 \mathrm{a}$ & $22.9 \mathrm{~b}$ & $7.89 \mathrm{a}$ \\
'Oroval-SRA335' & $3.61 \mathrm{a}$ & $3.35 \mathrm{a}$ & $22.9 \mathrm{~b}$ & $7.50 \mathrm{a}$ \\
'Oroval-Y45' & $3.48 \mathrm{a}$ & $3.28 \mathrm{a}$ & $21.0 \mathrm{~b}$ & $6.61 \mathrm{~b}$ \\
'Ponkan' & $2.66 \mathrm{c}$ & $3.57 \mathrm{a}$ & $14.9 \mathrm{c}$ & $4.97 \mathrm{~b}$ \\
'Ragheb-SRA386' & $3.02 \mathrm{~b}$ & $3.63 \mathrm{a}$ & $17.9 \mathrm{c}$ & $4.88 \mathrm{~b}$ \\
'Reina-SRA534' & $3.22 \mathrm{~b}$ & $3.23 \mathrm{a}$ & $17.5 \mathrm{c}$ & $6.23 \mathrm{~b}$ \\
'Tomatera-SRA535' & $4.05 \mathrm{a}$ & $3.45 \mathrm{a}$ & $30.4 \mathrm{a}$ & $9.92 \mathrm{a}$ \\
\hline CV (\%) & 9.18 & 7.79 & 21.12 & 28.25 \\
\hline
\end{tabular}

*Means followed by the same letter in each column do not significantly differ by the Scott-Knott test $(\mathrm{P}>0.05)$.

In the 2004-2008 period, the earliest bearer selections were 'Reina-SRA534', 'Bruno-SRA531', 'De Nules VCR', 'Clemenules-EECB128' and the 'Caçula-3' hybrid, with $25 \%<$ PCY $2<37 \%$, while the 'RaghebSRA386' and the 'Caffin-SRA385' selections had lower PCY2. The selections 'Oroval-SRA335', 'TomateraSRA535', 'Clemelin-IVIA335', 'Nules-SRA389', '2-KrMonreal', 'Commune-SRA88', 'Commune-SRA85', 'Commune-SRA92' and 'Marisol-EECB126' and the 'Cravo' standard variety had intermediate PCY2 values $(14 \%<$ PCY $2<25 \%$, Table 2$)$. The 'Oroval-Y45' and 'Ponkan' varieties and the 'Caçula-1' hybrid had about $10 \%$ of PCY2, while the 'Ragheb-SRA386' and 'CaffinSRA385' selections showed the lowest early bearing (3.2 and $0 \%$, respectively).

Lowest mean yield efficiency - YE - $\left(\mathrm{kg}\right.$ fruit $\mathrm{m}^{-3}$ canopy volume) was recorded in the 'Caffin-SRA385' selection $\left(0.60 \mathrm{~kg} \mathrm{~m}^{-3}\right)$, followed by the group of selections 'Oroval-SRA335', 'Tomatera-SRA535', 'Nules-SRA389', 'Rhageb', 'Oroval-Y45', '2-KrMonreal', 'Commune-SRA88', 'De Nules VCR', 'Commune-SRA92', 'Clemenules-EECB128', 'MarisolEECB126' and 'Caçula-1', with YE values varying from 2.02 to $3.12 \mathrm{~kg} \mathrm{~m}^{-3}$, lower than the YE of 'Cravo' and 'Ponkan' varieties (Table 2). A third group of selections, with intermediate YE values (3.37 to $\left.3.87 \mathrm{~m}^{-3}\right)$, included the 'Reina-SRA534', 'Bruno-SRA531', 'CommuneSRA85' and 'Caçula-3' mandarins. The 'ClemelinIVIA335' selection showed the highest YE $\left(4.88 \mathrm{~kg} \mathrm{~m}^{-3}\right)$, similar to the 'Cravo' $\left(4.98 \mathrm{~kg} \mathrm{~m}^{-3}\right)$ and 'Ponkan' $\left(4.84 \mathrm{~kg} \mathrm{~m}^{-3}\right)$ standard varieties.

Mean fruit weight was larger in the 'Ponkan' (196.5 g) and the 'Cravo' (170.7 g) standard varieties (Table 3). In general, most of the Clementine selections produced fairly small fruits, with two distinct weight classes: a group with larger fruit weight (123.2 to $147.0 \mathrm{~g}$ ), including the selections 'Oroval-SRA335', 'Tomatera-SRA535', 'Clemelin-IVIA335', 'Reina-SRA534', 'Nules-SRA389', 'Oroval-Y45', 'Commune-SRA88', 'De Nules VCR', 'Clemenules-EECB128' and the 'Caçula-1' and 'Caçula-3' hybrids, and a second group, formed by the selections 'Bruno-SRA531', 'Ragheb-SRA386', '2-Kr-Monreal', 'Commune-SRA85', 'Caffin-SRA385', 'CommuneSRA92' and 'Marisol-EECB126', with lower fruit weight (from 99.5 to $114.8 \mathrm{~g}$ ). Even such low fruit weight values were larger than the maximum fruit weight $(70 \mathrm{~g})$ reported in Corsica, France, for the 'Commune-SRA92' mandarin grafted onto 'Carrizo' citrange and trifoliate orange rootstocks (HUSSAIN et al., 2013). 
Table 2. Cumulative yield (CY), mean alternate bearing index (ABI), percentage of cumulative yield in the second commercial harvest (2005) (PCY2), and mean yield efficiency (YE) of twenty mandarin genotypes grafted on 'Swingle' citrumelo. Bebedouro, São Paulo State, Brazil 2004-2008.

\begin{tabular}{|c|c|c|c|c|c|}
\hline \multirow{2}{*}{ Genotypes } & \multicolumn{2}{|c|}{ CY } & \multirow[t]{2}{*}{$\mathrm{ABI}$} & \multirow{2}{*}{$\begin{array}{c}\text { PCY2 } \\
(\%)\end{array}$} & \multirow{2}{*}{$\begin{array}{c}\mathrm{YE} \\
\left(\mathrm{kg} \mathrm{m}^{-3}\right) *\end{array}$} \\
\hline & $\left(\mathrm{kg} \mathrm{plant}^{-1}\right)$ & $\left(\mathrm{t} \mathrm{ha}^{-1}\right)$ & & & \\
\hline '2 Kr Monreal' & $144.6 \mathrm{a}$ & $80.3 \mathrm{a}$ & $0.45 \mathrm{~b}$ & $19.1 \mathrm{~b}$ & $2,49 \mathrm{c}$ \\
\hline 'Bruno-SRA531' & $122.5 \mathrm{a}$ & $68.0 \mathrm{a}$ & $0.34 \mathrm{~b}$ & $26.1 \mathrm{a}$ & $3,87 \mathrm{~b}$ \\
\hline 'Caçula-1' & $115.2 \mathrm{a}$ & $64.0 \mathrm{a}$ & $0.69 \mathrm{a}$ & $12.0 \mathrm{c}$ & $2,55 \mathrm{c}$ \\
\hline 'Caçula-3' & $127.9 \mathrm{a}$ & $71.0 \mathrm{a}$ & $0.61 \mathrm{a}$ & $33.3 \mathrm{a}$ & $3,48 \mathrm{~b}$ \\
\hline 'Caffin-SRA385' & $16.5 \mathrm{c}$ & $9.1 \mathrm{c}$ & $0.72 \mathrm{a}$ & $0.00 \mathrm{~d}$ & $0,60 \mathrm{~d}$ \\
\hline 'Clemelin-IVIA335' & $75.0 \mathrm{~b}$ & $41.7 \mathrm{~b}$ & $0.40 \mathrm{~b}$ & $14.2 \mathrm{~b}$ & $4,88 \mathrm{a}$ \\
\hline 'Clemenules-EECB128' & $114.2 \mathrm{a}$ & $63.4 \mathrm{a}$ & $0.28 \mathrm{~b}$ & $37.0 \mathrm{a}$ & $3,12 \mathrm{c}$ \\
\hline 'Commune-SRA85' & $118.9 \mathrm{a}$ & $66.0 \mathrm{a}$ & $0.32 \mathrm{~b}$ & $16.1 \mathrm{~b}$ & $3,43 \mathrm{~b}$ \\
\hline 'Commune-SRA88' & $121.3 \mathrm{a}$ & $67.3 \mathrm{a}$ & $0.33 \mathrm{~b}$ & $14.2 \mathrm{~b}$ & $3,03 \mathrm{c}$ \\
\hline 'Commune-SRA92' & $125.1 \mathrm{a}$ & $69.5 \mathrm{a}$ & $0.37 \mathrm{~b}$ & $17.9 \mathrm{~b}$ & $2,42 \mathrm{c}$ \\
\hline 'Cravo' & $89.0 \mathrm{~b}$ & $49.4 \mathrm{~b}$ & $0.53 \mathrm{a}$ & $17.8 \mathrm{~b}$ & $4,98 \mathrm{a}$ \\
\hline 'De Nules VCR' & $110.9 \mathrm{a}$ & $61.6 \mathrm{a}$ & $0.37 \mathrm{~b}$ & $24.9 \mathrm{a}$ & $2,10 \mathrm{c}$ \\
\hline 'Marisol-EECB126' & $65.6 \mathrm{~b}$ & $36.4 \mathrm{~b}$ & $0.46 \mathrm{~b}$ & $24.5 \mathrm{~b}$ & $2,16 \mathrm{c}$ \\
\hline 'Nules-SRA389 & $100.8 \mathrm{a}$ & $56.0 \mathrm{a}$ & $0.53 \mathrm{a}$ & $17.8 \mathrm{~b}$ & $2,29 \mathrm{c}$ \\
\hline 'Oroval-SRA335' & $98.6 \mathrm{a}$ & $54.8 \mathrm{a}$ & $0.44 \mathrm{~b}$ & $16.7 \mathrm{~b}$ & $2,08 \mathrm{c}$ \\
\hline 'Oroval-Y45' & $113.7 \mathrm{a}$ & $63.2 \mathrm{a}$ & $0.58 \mathrm{a}$ & $7.1 \mathrm{c}$ & $2,45 \mathrm{c}$ \\
\hline 'Ponkan' & $121.6 \mathrm{a}$ & $67.5 \mathrm{a}$ & $0.68 \mathrm{a}$ & $9.8 \mathrm{c}$ & $4,84 \mathrm{a}$ \\
\hline 'Ragheb-SRA386' & $78.7 \mathrm{~b}$ & $43.7 \mathrm{~b}$ & $0.55 \mathrm{a}$ & $3.2 \mathrm{~d}$ & $2,02 \mathrm{c}$ \\
\hline 'Reina-SRA534' & $129.6 \mathrm{a}$ & $72.0 \mathrm{a}$ & $0.37 \mathrm{~b}$ & $36.1 \mathrm{a}$ & $3,37 \mathrm{~b}$ \\
\hline 'Tomatera-SRA535' & $156.6 \mathrm{a}$ & $87.0 \mathrm{a}$ & $0.38 \mathrm{~b}$ & $17.1 \mathrm{~b}$ & $2,98 \mathrm{c}$ \\
\hline $\mathrm{CV}(\%)$ & \multicolumn{2}{|c|}{25.45} & 22.04 & 29.00 & 23.40 \\
\hline
\end{tabular}
2008 period.

"Means followed by the same letter in each column do not significantly differ by the Scott-Knott test $(\mathrm{P}>0.05)$. Mean for the 2006-

In this study, the 'Ponkan' variety produced fruits with larger diameter, while the other evaluated mandarin genotypes were classified into three groups with different fruit diameter: a) the selections 'Oroval-SRA335', 'Reina-SRA534', 'Nules-SRA389', 'De Nules-VCR' and 'Clemenules-EECB128', that yielded fruits with the second largest diameter, ranging from 6.80 to 6.98 $\mathrm{cm}$, similar to the fruits of the 'Cravo' standard variety; b) a second group, including the selections 'TomateraSRA535', 'Oroval-Y45', 'Commune-SRA88', 'MarisolEECB126' and the 'Caçula-1' hybrid, with significantly smaller fruit diameters $(6.52$ to $6.70 \mathrm{~cm})$, and c) a third group of selections, including 'Bruno-SRA531', 'RaghebSRA386', '2-Kr-Monreal', 'Commune-SRA85', 'CaffinSRA385', 'Commune-SRA92' and the hybrids 'ClemelinIVIA335' and 'Caçula-3', that yielded the smallest fruit diameters (5.98 to $6.37 \mathrm{~cm}$ ). Hussan et al. (2013) reported large variation of fruit diameter in 'Commune-SRA92' clementines, and they also classified them into three different diameter classes $(39-52 \mathrm{~mm}, 46-60 \mathrm{~mm}$ and $54-74 \mathrm{~mm}$ ), independently of the rootstock variety. In the present study, the 'Commune-SRA92' selection had a mean fruit diameter of $6.22 \mathrm{~cm}$, which would be classified into the larger diameter class defined by the above-cited authors for this mandarin selection.
Fruit length also varied largely among the evaluated genotypes in the 2006-2008 period (years 5 to 7 after planting), and three distinct groups were identified: a) the largest group of selections, including 'Oroval-SRA335', 'Tomatera-SRA535', 'Nules-SRA389', 'De Nules-VCR', 'Clemenules-EECB128', 'Oroval-Y45', 'Reina-SRA534', 'Bruno-SRA531', 'Marisol-EECB126', 'CommuneSRA88' and the 'Caçula-3' hybrid, with fruit lengths varying from $5.96 \mathrm{~cm}$ for 'Commune-SRA 88 ' to $6.36 \mathrm{~cm}$ for 'Clemenules-EECB128', similar to mean fruit length of the 'Cravo' standard variety; b) a second group of varieties with smaller fruit lengths $(5.63 \mathrm{~cm}$ to $5.82 \mathrm{~cm})$, including the 'Ragheb-SRA386', 'Commune-SRA85', 'Commune-SRA92' and 'Caffin-SRA385' selections and the 'Caçula-1' hybrid. Selection '2-Kr-Monreal' yielded the shortest fruits, with only $5.24 \mathrm{~cm}$ length (Table 3 ).

The 'Caçula-3' hybrid yielded fruits with the highest juice content - JC - (Table 3). A second group of selections, with $42.6 \%<\mathrm{JC}<44.2 \%$ included 'Commune-SRA85', 'Commune-SRA92', the hybrid 'Caçula 1' and the 'Cravo' and 'Ponkan' standard varieties. JC of these varieties were closer of those reported by Hussain et al. (2013), which fitted a range of 43.0 to $48.0 \%$. Another group, including the selections 'Oroval-Y45', 'Oroval-SRA335', '2-KrMonreal', 'Commune-SRA88', 'Clemenules-EECB128', 
'Marisol-EECB126' and the 'Clemelin-IVIA335' hybrid, had significantly lower JC, varying from 34.7 to $38.3 \%$. Yet, the selections 'Reina-SRA534', 'Bruno-SRA531', 'Ragheb-SRA386', 'Nules-SRA389', 'Caffin-SRA385' and 'De Nules-VCR' had JC $<32.4 \%$ (Table 3).

In the 2006-2008 period, juice titratable acidity (TA) was lowest in the 'Ponkan' standard variety. A second group of selections, with intermediate TA values from 0.65 to $0.80 \%$, included 'Reina-SRA534', Caffin-SRA385', 'Marisol-EECB126' and 'Cravo' standard variety. All other selections had significantly higher TA, varying from 0.86 to $1.08 \%$ (Table 3 ). Hussain et al. (2013) reported lower acidity values, of 0.70 to $0.80 \%$ for the 'CommuneSRA92' mandarin onto different rootstocks, lower than TA recorded in this study $(0.98 \%)$ for the same variety grafted onto 'Swingle' citrumelo.

The evaluated mandarin genotypes were classified into four groups according to their juice TSS content (Table 3). In the first group, the 'Caçula-1' hybrid showed yielded highest TSS content (11.00 $\left.{ }^{\circ} \mathrm{Brix}\right)$, followed by the selections ' $2 \mathrm{Kr}$ Monreal', 'De Nules VCR', 'NulesSRA389, 'Commune-SRA85' and 'Commune-SRA88', with the second higher TSS contents (10.19 to $10.43^{\circ} \mathrm{Brix}$ ). A third group of selections, with $9.54<\mathrm{TSS}<10.08^{\circ} \mathrm{Brix}$, included 'Commune-SRA92', 'Clemenules-EECB128', 'Reina-SRA534', 'Tomatera-SRA535', 'RaghebSRA386' and the 'Ponkan' standard variety. Finally, the group formed by the hybrids 'Clemelin-IVIA335' and 'Caçula-3', and the selections 'Oroval-Y45', 'OrovalSRA335', 'Marisol-EECB126' and 'Cravo', with lowest TSS $\left(8.41<\right.$ TSS $<9.28^{\circ}$ Brix $)$.

Mean values of ratio in the juice followed the same trend as TA (Table 3). The 'Ponkan' standard variety stood out with its significantly higher ratio (20.42), being the earliest ripening variety, and was followed by a group including 'Reina-SRA535', 'Marisol-EECB126', 'De Nules VCR', 'Caffin-SRA389' and the 'Cravo' standard variety, with $13.15<$ ratio $<15.41$. All the remainder selections showed significantly lower ratio values $(9.21$ $<$ ratio $<12.70$ ). Citrus fruit quality is highly influenced by the climate, particularly for mandarins (REUTHER, 1973). These results confirm that typical subtropical climatic conditions, as those existing in the Bebedouro region (Figure 1), are not restrictive for commercial mandarin production, and adequate fruit yield and quality may be achieved with some selections. Nonetheless, the outstanding performance of the 'Ponkan' variety confirms its better adaptation to the local climatic conditions.

Eight years after planting, no symptoms of graft incompatibility were observed in the twenty studied scion/rootstock combinations, confirming that 'Swingle' citrumelo is a suitable rootstock for the various Clementine mandarins evaluated in this study, under the local soil and climatic conditions.

Under milder climatic conditions in the southern region of Brazil, 'Ponkan' trees grafted on seven different rootstocks had high fruit yield, but lower fruit juice content and ratio than those observed in this study (STENZEL et al., 2003). For 'Ponkan' and 'Nules-SRA389', Pio et al. (2006) found similar TSS, TA, and ratio than those observed in this study.

Except for their smaller fruit size and weight as compared to the 'Ponkan' and 'Cravo' standard varieties, most of the Clementine selections evaluated in this study overcame the quality standards established for the Brazilian market (CEAGESP, 2014b). For both standard varieties, minimum juice content of $35 \%$ to $40 \%, 9.0^{\circ}$ Brix SS and 9.5 ratio have been established. Fruit thinning could improve fruit size and weight of the Clementine selections grown under subtropical climate, attending the internal market requirements of larger fruit size (GONZATTO et al., 2016).

According to the United Nations normatives, all the selections evaluated in this study reached appropriate fruit size and ratio for export, i.e., minimum equatorial diameter $>35 \mathrm{~mm}$ and ratio $>7.0$, but only a few selections developed the adequate juice percentage of $40 \%$ (UNECE, 2014). Most of the evaluated selections were early-bearers (Table 3). This observation corroborates the results obtained by Silva et al. (2009). The authors also evaluated most of these selections in other orchards in the Bebedouro region, and found significant variations in the optimum harvest date among varieties, with 'De Nules VCR' and 'Bruno-SRA531' being the earlier bearers and earliest ripening selections. Both varieties may be harvested starting in February, while the 'ClemelinIVIA335' is harvested last of all, by September.

Fruit of the 'Caçula-1' hybrid had high juice content and acidity, as well as the highest TSS content. The 'Caçula-3' hybrid had similar attributes, except for its lower TSS, which could result in a later harvest period, probably with no flesh crystallization, due to its higher juice content (Table 3). Pio et al. (2000) also noted good fruit quality of the 'Caçula-3' and 'Caçula-4' hybrids, with the chance of developing seedless fruits. However, ABI was high for both of these hybrids (Table 3).

The 'Marisol-EECB126', 'De Nules-VCR', 'Reina-SRA534' and 'Caffin-SRA385' clementines had low juice content and high ratio, suggesting that they could be harvested earlier. 'Caffin-SRA385', 'Bruno-SRA531' and 'Nules-SRA389' were also evaluated in the South of Morocco (CHAHIDI et al., 2007), where 'Caffin-SRA385' and 'Bruno-SRA531' showed lower juice content than 'Nules-SRA389', but with a similar ratio. Although fruit flesh granulation was not evaluated in this study, this disorder should probably occur in the selections with JC $<35 \%$ (ERICKSON, 1968; RITENOUR et al., 2004).

'Ponkan' mandarin grafted on Swingle citrumelo outstood when compared to the other mandarin selections of this study, due to its higher yield efficiency and the production of larger and sweeter fruit, which are more suitable for the internal market. However, some of the Clementine selections evaluated in this study also showed good performance. 
Table 3. Fruit weight, diameter and length, and juice content (JC), titratable acidity (TA), total soluble solid content (TSS) and ratio (TSS/TA) of twenty mandarin genotypes grafted on 'Swingle' citrumelo. Bebedouro, São Paulo State, Brazil, 2006-2008*.

\begin{tabular}{lccccccc}
\hline Genotypes & $\begin{array}{c}\text { Weight } \\
(\mathrm{g})\end{array}$ & $\begin{array}{c}\text { Diameter } \\
(\mathrm{cm})\end{array}$ & $\begin{array}{c}\text { Length } \\
(\mathrm{cm})\end{array}$ & $\begin{array}{c}\text { JC } \\
(\%)\end{array}$ & $\begin{array}{c}\text { TA } \\
(\%)\end{array}$ & $\begin{array}{c}\text { TSS } \\
\left({ }^{\circ} \text { Brix }\right)\end{array}$ & $\begin{array}{c}\text { Ratio } \\
(\mathrm{TSS} / \mathrm{TA})\end{array}$ \\
\hline '2 Kr Monreal' & $99.5 \mathrm{~d}$ & $5.98 \mathrm{~d}$ & $5.24 \mathrm{~d}$ & $35.6 \mathrm{c}$ & $0.88 \mathrm{a}$ & $10.24 \mathrm{~b}$ & $11.70 \mathrm{c}$ \\
'Bruno-SRA531' & $108.5 \mathrm{~d}$ & $6.30 \mathrm{~d}$ & $6.12 \mathrm{~b}$ & $30.9 \mathrm{~d}$ & $0.86 \mathrm{a}$ & $9.54 \mathrm{c}$ & $11.85 \mathrm{c}$ \\
'Caçula-1' & $132.7 \mathrm{c}$ & $6.57 \mathrm{c}$ & $5.76 \mathrm{c}$ & $44.2 \mathrm{~b}$ & $1.08 \mathrm{a}$ & $11.00 \mathrm{a}$ & $11.03 \mathrm{c}$ \\
'Caçula-3' & $130.8 \mathrm{c}$ & $6.37 \mathrm{~d}$ & $6.03 \mathrm{~b}$ & $49.3 \mathrm{a}$ & $0.96 \mathrm{a}$ & $8.87 \mathrm{~d}$ & $9.21 \mathrm{c}$ \\
'Caffin-SRA385' & $105.4 \mathrm{~d}$ & $6.33 \mathrm{~d}$ & $5.82 \mathrm{c}$ & $29.5 \mathrm{~d}$ & $0.73 \mathrm{~b}$ & $9.98 \mathrm{c}$ & $15.41 \mathrm{~b}$ \\
'Clemelin-IVIA335' & $123.2 \mathrm{c}$ & $6.31 \mathrm{~d}$ & $6.07 \mathrm{~b}$ & $35.8 \mathrm{c}$ & $0.93 \mathrm{a}$ & $9.09 \mathrm{~d}$ & $9.86 \mathrm{c}$ \\
'Clemenules-EECB128' & $147.0 \mathrm{c}$ & $6.98 \mathrm{~b}$ & $6.36 \mathrm{~b}$ & $35.6 \mathrm{c}$ & $0.91 \mathrm{a}$ & $9.78 \mathrm{c}$ & $11.17 \mathrm{c}$ \\
'Commune-SRA85' & $114.8 \mathrm{~d}$ & $6.27 \mathrm{~d}$ & $5.76 \mathrm{c}$ & $43.3 \mathrm{~b}$ & $0.98 \mathrm{a}$ & $10.43 \mathrm{~b}$ & $10.75 \mathrm{c}$ \\
'Commune-SRA88' & $124.2 \mathrm{c}$ & $6.52 \mathrm{c}$ & $5.96 \mathrm{~b}$ & $38.3 \mathrm{c}$ & $0.97 \mathrm{a}$ & $10.19 \mathrm{~b}$ & $10.64 \mathrm{c}$ \\
'Commune-SRA92' & $113.4 \mathrm{~d}$ & $6.22 \mathrm{~d}$ & $5.63 \mathrm{c}$ & $42.6 \mathrm{~b}$ & $0.98 \mathrm{a}$ & $10.08 \mathrm{c}$ & $10.35 \mathrm{c}$ \\
'Cravo' & $170.7 \mathrm{~b}$ & $7.24 \mathrm{~b}$ & $6.31 \mathrm{~b}$ & $45.3 \mathrm{~b}$ & $0.65 \mathrm{~b}$ & $8.41 \mathrm{~d}$ & $13.15 \mathrm{~b}$ \\
'De Nules VCR' & $133.5 \mathrm{c}$ & $6.94 \mathrm{~b}$ & $6.21 \mathrm{~b}$ & $31.1 \mathrm{~d}$ & $0.84 \mathrm{a}$ & $10.24 \mathrm{~b}$ & $14.03 \mathrm{~b}$ \\
'Marisol-EECB126' & $112.5 \mathrm{~d}$ & $6.57 \mathrm{c}$ & $6.00 \mathrm{~b}$ & $36.9 \mathrm{c}$ & $0.76 \mathrm{~b}$ & $8.74 \mathrm{~d}$ & $14.08 \mathrm{~b}$ \\
'Nules-SRA389 & $135.9 \mathrm{c}$ & $6.87 \mathrm{~b}$ & $6.21 \mathrm{~b}$ & $30.5 \mathrm{~d}$ & $0.86 \mathrm{a}$ & $10.29 \mathrm{~b}$ & $12.70 \mathrm{c}$ \\
'Oroval-SRA335' & $132.2 \mathrm{c}$ & $6.84 \mathrm{~b}$ & $6.18 \mathrm{~b}$ & $35.9 \mathrm{c}$ & $0.95 \mathrm{a}$ & $8.88 \mathrm{~d}$ & $9.89 \mathrm{c}$ \\
'Oroval-Y45' & $130.5 \mathrm{c}$ & $6.70 \mathrm{c}$ & $6.22 \mathrm{~b}$ & $34.7 \mathrm{c}$ & $0.98 \mathrm{a}$ & $9.28 \mathrm{~d}$ & $9.58 \mathrm{c}$ \\
'Ponkan' & $196.5 \mathrm{a}$ & $7.77 \mathrm{a}$ & $6.97 \mathrm{a}$ & $39.5 \mathrm{~b}$ & $0.51 \mathrm{c}$ & $9.67 \mathrm{c}$ & $20.42 \mathrm{a}$ \\
'Ragheb-SRA386' & $113.9 \mathrm{~d}$ & $6.36 \mathrm{~d}$ & $5.64 \mathrm{c}$ & $26.7 \mathrm{~d}$ & $0.96 \mathrm{a}$ & $9.61 \mathrm{c}$ & $10.07 \mathrm{c}$ \\
'Reina-SRA534' & $133.1 \mathrm{c}$ & $6.80 \mathrm{~b}$ & $6.20 \mathrm{~b}$ & $32.4 \mathrm{~d}$ & $0.80 \mathrm{~b}$ & $9.94 \mathrm{c}$ & $14.03 \mathrm{~b}$ \\
'Tomatera-SRA535' & $124.4 \mathrm{c}$ & $6.58 \mathrm{c}$ & $6.06 \mathrm{~b}$ & $35.5 \mathrm{c}$ & $0.93 \mathrm{a}$ & $9.91 \mathrm{c}$ & $11.12 \mathrm{c}$ \\
\hline CV (\%) & 5.97 & 3.12 & 3.41 & 7.96 & 8.65 & 3.39 & 11.18 \\
\hline
\end{tabular}

Means followed by the same letter in each column do not significantly differ by the Scott-Knott test $(\mathrm{P}>0.05)$.

*Fruits were annually harvested in May.

\section{Conclusions}

'Ponkan' trees performed similarly or outperformed other mandarin selections in terms of yield efficiency, with larger fruits and earlier ripening.

The 'Reina-SRA534' selection had the greatest potential, because it combined good fruit quality with medium-size fruit, high production and early bearing.

The 'De Nules VCR' and 'Tomatera-SRA535' selections had high yield, low alternate-bearing and fine fruit quality, despite of their large plant size.

Good performance of Clementine selections and hybrids encourages further studies on appropriate cultural practices for growing this group of mandarins under subtropical climatic conditions.

\section{Acknowledgements}

Authors acknowledge the Fundacão de Amparo à Pesquisa do Estado de São Paulo (FAPESP) for financial support (Process 2004/16077-3); thanks to the Centro APTA Citros Sylvio Moreira/IAC, in Cordeirópolis, SP, Brazil, and to the Agrumes SRA Agricultural Research Station, in Corsica, France, for kindly providing part of the plant materials; thanks also to the Estação Experimental de Citricultura de Bebedouro for providing the experimental area and technical and administrative support, and to Prof. Dr. Luiz Carlos Donadio (Unesp/FCAV), who introduced the evaluated selections in the EECB.

\section{References}

ABEDI-GHESHLAGHI, E.; FIFAEI, R. Effect of planting density on quantitative and quality traits of Unshiu mandarin (Citrus unshiu) on Flying Dragon rootstock. Seed and Plant Production Journal, Karaj, n.28, p.8193, 2012.

BARBOSA, J.C.; MALDONADO JUNIOR, W. Experimentação agronômica \& AgroEstat. Jaboticabal: Gráfica Multipress, 2015. 396p.

BASSAL, M.A. Growth, yield and fruit quality of 'Marisol' clementine grown on four rootstocks in Egypt. Scientia Horticulturae, New York, n.119, p.132-137, 2009. 
BOVÉ, J.M.; AYRES, A.J. Etiology of three recent diseases of citrus in São Paulo State: sudden death variegated chlorosis and Huanglongbing. IUBMB Life, Oklahoma City, v.59, p.346-354, 2007.

CANTUARIAS-AVILÉS, T.E.; MOURÃO FILHO, F.A.A.; STUCHI, E.S.; SILVA, S.R.; ESPINOZA, E. Horticultural performance of 'Folha Murcha' sweet orange onto twelve rootstocks. Scientia Horticulturae, New York, n.129, p.259-265, 2011.

CEAGESP - Companhia de Entrepostos e Armazéns Gerais de São Paulo. Citrus classification standards. Normas de classificação: citros de mesa. São Paulo, 2014. Disponível em: <http://www.ceagesp.gov.br/produtor/ classific/>. Acesso em: 18 ago. 2014a.

CEAGESP - Companhia de Entrepostos e Armazéns Gerais de São Paulo. Cotações 2014. São Paulo, 2014. Disponível em: <http://www.ceagesp.gov.br/cotacoes>. Acesso em: 18 aug. 2014b.

CHAHIDI, B.; EL-OTMANI, M.; LURO, F.; SRAIRI, I.; TIJANE, M. Fruit quality characterization of seven clementine cultivars. Journal of Applied Horticulture, Lucknow, n.9, p.162-166, 2007.

ERICKSON, L.C. The general citrus physiology. In: REUTHER, W.; BATCHELOR, L.D.; WEBBER, H.J. (Ed.). The citrus industry. Davis: University of California, Division of Agricultural Sciences, 1968. v.2, p.86-126.

FAO- Food and Agriculture Organization. Agricultural production index. Rome. 2017. Disponível em: $<$ http:// faostat.fao.org>. Acesso em: 29 aug. 2017.

GEORGIOU, A. Evaluation of rootstocks for 'Clementine' mandarin in Cyprus. Scientia Horticulturae, New York, v.93, p.29-38. 2002.

GONZATTO, M.P.; BÖETTCHER, G.N.; SCHNEIDER, L.A.; LOPES, Â.A.; JÚNIOR, S.; CAMARGO, J.; SCHWARZ, S.F. 3, 5, 6-trichloro-2pyridinyloxyacetic acid as effective thinning agent for fruit of'Montenegrina'mandarin. Ciência Rural, Santa Maria, v.46, n.12, p.2078-2083, 2016.

HODGSON, R.W. Horticultural varieties of citrus. In: REUTHER, W.; BATCHELOR, L.D.; WEBBER, H.J. (Ed.). The citrus industry 1. Riverside: University of California, 1967.

HUSSAIN, S.; CURK, F.; ANJUM, M.A.; PAILLY, O.; TISON, G. Performance evaluation of common clementine on various citrus rootstocks. Scientia Horticulturae, New York, v.150, p.278-282, 2013.
IBGE - Instituto Brasileiro de Geografia e Estatística. Produção agrícola municipal. Rio de Janeiro, 2013. Disponível em: $\leq$ http://www.ibge.gov.br $>$. Acesso em: 16 mar. 2015.

MOLINARI, H.B.C.; BESPALHOK, J.C.; KOBAYASHI, A.K.; PEREIRA, L.F.P.; VIEIRA, L.G.E. Agrobacterium tumefaciens-mediated transformation of Swingle citrumelo (Citrus paradisi Macf. $\times$ Poncirus trifoliata L. Raf.) using thin epicotyl sections. Scientia Horticulturae, New York, v.99, n.3, p.379-385, 2004.

PERES, N.A.R.; AGOSTINI, J.P.; TIMMER, L.W. Outbreaks of Alternaria brown spot of citrus in Brazil and Argentina. Plant Disease, London, v.87, n.6, p.750-750, 2003.

PIO, R.M.; AZEVEDO, F.A.; DE NEGRI, J.D.; FIGUEIREDO, J.O.; GARCIA, V.X.P. Characteristics of Fremont variety compared to Ponkan and Clementina Nules tangerines (in Portuguese, with abstract in English). Revista Brasileira de Fruticultura, Jaboticabal, v.28, p.222-226, 2006.

PIO, R.M.; FIGUEIREDO, J.O.; STUCHI, E.S.; CARDOSO, S.A.B. Scion cultivars. In: MATTOS JUNIOR, D.; NEGRI, J.D.; PIO, R.M.; POMPEU JUNIOR, P. (Ed.). Citros. Campinas: Instituto Agronômico de Campinas/Fundag, 2005.

PIO, R.M.; MINAMI, K.; FIGUEIREDO, J.O.; POMPEU JUNIOR, J. Characterization and evaluation of two new hybrid cultivars of 'Clementine' mandarin (in Portuguese, with abstract in English). Laranja, Cordeirópolis, v.21, p.149-159, 2000.

REIS, R.F.; ALMEIDA, T.F.; STUCHI, E.S.; GOES, A. Susceptibility of citrus species to Alternaria alternata, the causal agent of the Alternaria brown spot. Scientia Horticulturae, New York, v.113, p.336-342, 2007.

REUTHER, W. Climate and citrus behavior. In: W. REUTER (Ed.). The citrus industry. $2^{\text {nd }}$ ed. Berkeley: University of California Press, 1973. p.280-337.

RITENOUR, M.A.; ALBRIGO, L.G.; BURNS, J.K.; MILLER, W.M. Granulation in Florida Citrus. Procedings of the Florida State Horticultural Sociecty, Lake Alfred, v.117, p.358-361, 2004

SAUNT, J. The mandarin. In: SAUNT, J. (Ed.). Citrus varieties of the world Bowthorpe. Norwich: Sinclair International Limited, 2000. p.43-87.

SILVA, S.R.; OLIVEIRA, J.C.; STUCHI, E.S.; REIFF, E.T. Quality and maturation of tangerines and their hybrids in São. Revista Brasileira de Fruticultura, Jaboticabal, v.31, n.4, p.977-986, 2009. 
SOLEL, Z.; KIMCHI, M. Susceptibility and resistance of citrus genotypes to Alternaria alternata pv. citri. Journal of Phytopathology, Berlin, v.145, n.8/9, p.389-391, 1997.

SOUZA, M.C.; STUCHI, E.S.; GOES, A. Evaluation of tangerine hybrid resistance to Alternaria alternata. Scientia Horticulturae, New York, v.123, p.1-4, 2009.

STENZEL, N.M.C.; NEVES, C.S.V.J.; GOMES, J.C.; MEDINA, C.C. Performance of Ponkan mandarin on seven rootstocks in Southern Brazil. HortScience, Alexandria, v.38, p.176-178, 2003.
UNECE - United Nations Economic Commission for Europe. UNECE standard FFV-14 concerning the marketing and commercial quality control of Citrus Fruit. New York and Geneva: UNECE, 2014. Disponível em: $<$ www.unece.org $>$. Acesso em : 02 out. 2014. 